\title{
Computed Tomography Use on Age Estimation in Forensic Dentistry: A Review
}

\section{Queiroz $\mathrm{CL}^{1}$, Silva $\mathrm{RF}^{2}$ and Silva $\mathrm{RHA}^{*_{1}}$}

${ }^{1}$ Department of Stomatology, Public Health and Forensic Dentistry, School of Dentistry of Ribeirao Preto, University of Sao Paulo, State of Sao Paulo, Brazil

${ }^{2}$ Department of Forensic Dentistry, School of Dentistry, Federal University of Goias, State of Goias, Brazil

*Corresponding author: Silva RHA, DDS MSc PhD, School of Dentistry of Ribeirao Preto, University of Sao Paulo, Department of Dentistry, Public Health and Forensic Dentistry, Avenida do Cafe s/n CEP: 14040-904, Ribeirao Preto, SP, Brazil, Tel: +55 163315 3969, E-mail: ricardohenrique@usp.br

Citation: Queiroz CL, Silva RF, Silva RHA (2016) Computed Tomography Use on Age Estimation in Forensic Dentistry: A Review. J Forensic Sci Criminol 4(1): 105. doi: 10.15744/2348-9804.4.105

Received Date: December 18, 2015 Accepted Date: February 25, 2016 Published Date: February 26, 2016

\begin{abstract}
Computed tomography is an alternate imaging modality which can be used to estimate age and to aid on human identification in Forensic Dentistry. This paper proposes to review the literature about the computed tomography (CT) use on age estimation in Forensic Dentistry. The searched database was PubMed for the terms: 'computed tomography' AND 'age estimation' AND 'forensic dentistry'. Eighteen listed studies were analyzed. They should be research that analyzed anatomical structures related to Dentistry without alteration of these structures and they had been written in the English language. Then thirteen studies were reviewed and the others were excluded. The computed tomography use to estimate age through dental age estimation methods and calculations to obtain the ratio between pulp volume and tooth volume displays significant accuracy.

Keywords: Computed tomography; Age estimation; Forensic Dentistry
\end{abstract}

\section{Introduction}

Forensic Dentistry has become an integral part of Forensic Sciences over the past 100 years that utilizes dental or orofacial findings to serve the judicial system. This has been due to the dedication of many researchers that established the essential role that Forensic Dentistry plays, mainly in the identification of human remains [1].

The data obtained from the oral cavity can contribute to estimate age and to determine sex of an unknown individual or provide information needed to Justice and security. It requires interdisciplinary knowledge. Furthermore, these data can narrow the search range of an individual and play a key role in the victim identification [2].

Classic methods for forensic dental identification are the clinically used radiological documentation techniques such as dental periapical radiographs, bitewing films and panoramic x-ray. In these methods, dental changes related to age like tooth eruption, tooth calcification, attrition, periodontal diseases, secondary dentin deposition, root translucency, cementum apposition, root resorption, color changes and increase in root roughness are analyzed [3-60].

An alternate imaging modality that is beginning to make inroads into medicolegal death investigation around the world is computed tomography (CT) [61-63]. The clinical introduction of cone-beam CT creates new opportunities to get 3-dimensional (3D) tooth radiographs. It has been shown that $\mathrm{CT}$ scans cause no magnification errors due to geometric distortion, which is a common problem in conventional radiography $[64,65]$. Typically, extraction and sectioning of teeth are required to quantify morphological changes, for obtain data like age and sex, but is not always a viable option. CT, however, provides a noninvasive alternative [66].

The aim of this study was to review the literature about the CT use on age estimation in Forensic Dentistry.

\section{Material and Methods}

The searched database was PubMed for the terms: 'computed tomography' AND 'age estimation' AND 'forensic dentistry'. All listed studies were analyzed. They should be research that analyzed anatomical structures related to Dentistry without alteration of these structures and they had been written in the English language. 


\section{Results}

Eighteen listed studies were analyzed. Five studies were not according to descriptions in Material and methods were excluded. Then thirteen studies were reviewed (Table 1).

\begin{tabular}{|c|c|c|c|c|}
\hline Authors & Age range (years) & $\begin{array}{l}\text { Teeth/ } \\
\text { anatomical region }\end{array}$ & Analysis type & Key points \\
\hline $\begin{array}{l}\text { Aboshi, Takahashi } \\
\text { and Komuro (2010) [67] }\end{array}$ & $20-78$ & $\begin{array}{l}\text { Mandibular first and } \\
\text { second premolars }\end{array}$ & $\begin{array}{l}\text { Ratio between pulp volume and } \\
\text { tooth volume. }\end{array}$ & $\begin{array}{l}\text { The coronal one third of the root } \\
\text { showed significant correlation at all } \\
\text { age groups. }\end{array}$ \\
\hline $\begin{array}{l}\text { Bassed, Briggs and } \\
\text { Drummer (2011) [68] }\end{array}$ & $15-25$ & Mandibular third molar & $\begin{array}{l}\text { Compare the developmental } \\
\text { scores obtained from both CT } \\
\text { images and conventional OPT }{ }^{*} \text { - } \\
\text { Demirjian method [69]. }\end{array}$ & $\begin{array}{l}\text { It was found excellent agreement of } \\
\text { Demirjian scores between CT images } \\
\text { and conventional OPT }{ }^{*} \text { [69]. }\end{array}$ \\
\hline Brough, et al. (2014) [70] & $0-18$ & Mandibles and maxillas & $\begin{array}{c}\text { Age estimations based } \\
\text { on CT data compared } \\
\text { with those using OPT }- \text { QMUL }^{\dagger} \\
\text { method and Demirjian method } \\
{[13,69,71,72] .}\end{array}$ & $\begin{array}{l}\text { It was obtained almost perfect } \\
\text { agreement between mean estimated } \\
\text { age using CT and mean estimated } \\
\text { age using OPT }\end{array}$ \\
\hline $\begin{array}{l}\text { Cantekin, Sekerci and } \\
\text { Buyuk (2013) [73] }\end{array}$ & $9-25$ & $\begin{array}{l}\text { Mandibular } \\
\text { third molar }\end{array}$ & $\begin{array}{l}\text { Tooth development and relation } \\
\text { to chronological age on CT } \\
\text { images } \\
\text { - Demirjian method [72]. }\end{array}$ & $\begin{array}{c}\text { Strong correlation between age and } \\
\text { third molar } \\
\text { development. }\end{array}$ \\
\hline Graham, et al. (2010) [74] & Up to 15 & $\begin{array}{l}\text { Second permanent } \\
\text { molar }\end{array}$ & $\begin{array}{l}\text { The last stages of its root - } \mathrm{MFH}^{\ddagger} \\
\text { method. }[75,76]\end{array}$ & $\begin{array}{l}\text { The MFH method was found to } \\
\text { systematically underestimate the } \\
\text { chronological age }[75,76] \text {. }\end{array}$ \\
\hline Lalys, et al. (2011) [77] & Fetuses: 19-41 WA, & $\begin{array}{l}\text { Germs of deciduous } \\
\text { teeth and mandibles }\end{array}$ & $\begin{array}{l}\text { Relationships between fetal } \\
\text { age and deciduous germ } \\
\text { measurements. }\end{array}$ & $\begin{array}{c}\text { The most precise age evaluation } \\
\text { obtained, so greater accuracy is still } \\
\text { needed. }\end{array}$ \\
\hline Pinchi, et al. (2015) [78] & $10-80$ & $\begin{array}{l}\text { Maxillary left central } \\
\text { incisor }\end{array}$ & $\begin{array}{l}\text { Ratio between pulp volume and } \\
\text { hard tissues volume. }\end{array}$ & $\begin{array}{l}\text { This ratio was statistically significant } \\
\text { as a predictor for age estimation. }\end{array}$ \\
\hline Sakuma, et al. (2013) [79] & $14-79$ & $\begin{array}{l}\text { Left or right } \\
\text { mandibular first } \\
\text { premolars }\end{array}$ & $\begin{array}{l}\text { Ratio between pulp volume and } \\
\text { tooth volume. }\end{array}$ & $\begin{array}{c}\text { Estimated age correlated significantly } \\
\text { with the pulp cavity to tooth volume } \\
\text { ratio. }\end{array}$ \\
\hline Someda, et al. (2009) [80] & $12-79$ & $\begin{array}{l}\text { Mandibular central } \\
\text { incisors }\end{array}$ & $\begin{array}{l}\text { Volumes of enamel, dentin, and } \\
\text { pulp cavity. }\end{array}$ & $\begin{array}{l}\text { The whole } \\
\text { tooth and the crown region } \\
\text { presented slightly higher correlations } \\
\text { for ratio between pulp volume and } \\
\text { tooth volume } \\
\text { with enamel excluded. }\end{array}$ \\
\hline Star, et al. (2011) [81] & $10-65$ & $\begin{array}{l}\text { Incisors, canines and } \\
\text { premolars }\end{array}$ & $\begin{array}{l}\text { Ratio between pulp volume and } \\
\text { tooth volume. }\end{array}$ & $\begin{array}{l}\text { This ratio was } \\
\text { strongest related to age on incisors. }\end{array}$ \\
\hline Tardivo, et al. (2011) [82] & $14-74$ & Canines & $\begin{array}{l}\text { Ratio between pulp volume and } \\
\text { tooth volume. }\end{array}$ & $\begin{array}{l}\text { Negative correlation between this } \\
\text { ratio and age. }\end{array}$ \\
\hline $\begin{array}{l}\text { Vandevoort, et al. (2004) } \\
\text { [83] }\end{array}$ & $24-66$ & $\begin{array}{l}\text { Incisors, canines and } \\
\text { premolars }\end{array}$ & $\begin{array}{l}\text { Ratio between pulp volume and } \\
\text { tooth volume. }\end{array}$ & $\begin{array}{l}\text { Rather weak correlation between this } \\
\text { ratio and biological age. }\end{array}$ \\
\hline $\begin{array}{l}\text { Yang, Jacobs and Willems } \\
\text { (2006) [66] }\end{array}$ & $23-70$ & $\begin{array}{l}\text { Incisors, canines and } \\
\text { premolars }\end{array}$ & $\begin{array}{l}\text { Ratio between pulp volume and } \\
\text { tooth volume. }\end{array}$ & $\begin{array}{l}\text { Moderate correlation between this } \\
\text { ratio and biological age. }\end{array}$ \\
\hline
\end{tabular}

"OPT - orthopantomography

QMUL - London Atlas of Human Tooth Development and Eruption

${ }^{\ddagger}$ MFH - method proposed by Moorrees, Fanning and Hunt

Table 1: Reviewed studies from PubMed database for the terms: 'computed tomography' AND 'age estimation' AND 'forensic dentistry'

\section{Discussion}

Age estimation is one of the main data that aid in human identification process. The dental changes quantification generally had used destructive methods such as the extraction and sectioning of the tooth that are unsuitable in living subjects and even for specific religious, cultural, or scientific reasons. Therefore, conservative techniques for age estimation like two dimensional images (conventional radiography) and mainly three dimensional images (CT) have been most studied [78].

CT has been gradually accepted due to aid and the potential replacement from conventional radiography by reproducing and augmenting of the information available. This has generated suitable resolution and high quality image reconstructions in multiple planes and three dimensional modelling of slices. Hard tissues images like teeth and bones are assessed using CT in any plane without invasive procedures, offering considerable practical and aesthetic benefits [70]. 
The reviewed studies demonstrated to estimate age through CT images applying dental age estimation methods which determine stages of teeth development and eruption.

Bassed, Briggs and Drummer, Brough, et al. and Cantekin, Sekerci and Buyuk used Demirjian method to analyze and to determine the score $[68-70,72,73]$. The first and second studies compared CT images to OPT of deceased individuals and human remains respectively, and found excellent agreement and almost perfect agreement, respectively, between these imaging modalities [68,70]. The third study evaluated CT images from patients' records and it was showed strong correlation between age and third molar development [73]. The differences among these studies are teeth/anatomical region and age range according to Table 1.

An important observation from the second study is that also used QMUL method [71] and found the same agreement. Moreover Graham, et al. used a different age estimation method compared above authors, a method proposed by MFH and they observed systematically underestimate the chronological age [74-76].

The four studies which used dental age estimation methods three carried out postmortem evaluation and two of these demonstrated significant agreement between CT images and conventional OPT [11,13,14,17,18,68,70,73,74].

The other reviewed studies calculated the ratio between pulp volume and tooth volume [9,20-25]. The choice of this method is due to the perception of the reduction of the pulp chamber volume concerning to deposition of secondary dentin related to age in radiological images like radiographs and CT [67,78-83].

Aboshi, Takahashi and Komuro and Sakuma, et al. evaluated mandibular premolars and found the coronal one third of the root showed significant correlation at all age groups at the first study and the estimated age correlated significantly with the pulp cavity to tooth volume ratio according to second study $[67,79]$.

Pinchi, et al. and Someda, et al. analyzed maxillary and mandibular central incisors, respectively, and obtained the ratio between the pulp volume and the hard tissues volume was statistically significant as a predictor for age estimation and the whole tooth and the crown region presented slightly higher correlations for ratio between pulp volume and tooth volume with enamel excluded, respectively $[78,80]$.

Star, et al. selected incisors, canines and premolars and noted the ratio between pulp volume and tooth volume was strongest related to age on incisors [81]. On the other hand, Tardivo, et al. selected only canines and observed a negative correlation between this ratio and age [82].

Vandevoort, et al. and Yang, Jacobs and Willems studied incisors, canines and premolars and found rather weak and moderate correlation, respectively, between the ratio pulp volume and tooth volume and biological age $[66,83]$.

Lalys, et al. developed a different study analyzing fetal age through deciduous germ measurements and they showed the most precise age evaluation obtained, so greater accuracy is still needed [77].

The nine studies which calculated pulp volume and tooth volume ratio, one carried out postmortem evaluation and the others evaluated CT images of extracted teeth or patients [21,66,67,78-83].

Computed tomography is capable of providing accurate and measurable 3-dimensional images of different teeth, maxilla and mandible like the studies analyzed in this review [70].

Most studies evaluated teeth which assume a primary role in the identification of remains when postmortem changes, traumatic tissue injury, or lack of a fingerprint record invalidate the use of visual or fingerprint methods. The identification of dental remains are of primary importance when the deceased person is skeletonized, decomposed, burned, or dismembered. The main advantage of dental evidence is that, like other hard tissues, it is often preserved after death. Even the status of a person's teeth change throughout life and the combination of decayed, missing, and filled teeth is measurable and comparable to any fixed point in time. Teeth can survive virtually intact long after other soft tissue and skeletal tissue have been destroyed by decay or incineration [1].

Therefore computed tomography is important, in order to capture anatomical features images of the dention and skull to assess age estimation [68].

\section{Conclusion}

The computed tomography use to estimate age through dental age estimation methods and calculations to obtain the ratio between pulp volume and tooth volume displays significant accuracy.

\section{References}

1. Verma AK, Kumar S, Rathore S, Pandey A (2014) Role of dental expert in forensic odontology. Natl J Maxillofac Surg 5: 2-5.

2. Ata-Ali J, Ata-Ali F (2014) Forensic dentistry in human identification: A review of the literature. J Clin Exp Dent 6: e162-7.

3. Erbudak HÖ, Ozbek M, Uysal S, Karabulut E (2012) Application of Kvaal et al's age estimation method to panoramic radiographs from Turkish individuals. Forensic Sci Int 219: 141-6.

4. Patel PS, Chaudhary AR, Dudhia BB, Bhatia PV, Soni NC, et al. (2015) Accuracy of two dental and one skeletal age estimation methods in 6-16 year old Gujarati children. J Forensic Dent Sci 7: 18-27. 
5. Mohammed RB, Sanghvi P, Perumalla KK, Srinivasaraju D, Srinivas J, et al. (2015) Accuracy of four dental age estimation methods in southern Indian children. J Clin Diagn Res 9: HC01-8.

6. Bommannavar S, Kulkarni M (2015) Comparative study of age estimation using dentinal translucency by digital and conventional methods. J Forensic Dent Sci 7: 71-5.

7. Agarwal N, Ahuja P, Sinha A, Singh A (2012) Age estimation using maxillary central incisors: A radiographic study. J Forensic Dent Sci 4: 97-100.

8. Ajmal M, Assiri KI, Al-Ameer KY, Assiri AM, Luqman M (2012) Age estimation using third molar teeth: A study on southern Saudi population. J Forensic Dent Sci 4: 63-5.

9. Almeida MS, Pontual Ados A, Beltrão RT, Beltrão RV, Pontual ML (2013) The chronology of second molar development in Brazilians and its application to forensic age estimation. Imaging Sci Dent 43: 1-6.

10. AlQahtani SJ, Hector MP, Liversidge HM (2014) Accuracy of dental age estimation charts: Schour and Massler, Ubelaker and the London Atlas. Am J Phys Anthropol 154: 70-8.

11. Altalie S, Thevissen P, Fieuws S, Willems G (2014) Optimal dental age estimation practice in United Arab Emirates' children. J Forensic Sci 59: 383-5.

12. Altunsoy M, Nur BG, Akkemik O, Ok E, Evcil MS (2015) Applicability of the Demirjian method for dental age estimation in western Turkish children. Acta Odontol Scand 73: 121-5.

13. Ambarkova V, Galić I, Vodanović M, Biočina-Lukenda D, Brkić H (2014) Dental age estimation using Demirjian and Willems methods: cross sectional study on children from the Former Yugoslav Republic of Macedonia. Forensic Sci Int 234: 187.e1-7.

14. Baghdadi ZD (2013) Dental maturity of Saudi children: Role of ethnicity in age determination. Imaging Sci Dent 43: 267-72.

15. Baghdadi ZD (2014) Testing international dental maturation scoring system and population-specific Demirjian versions on Saudi sub-population. J Clin Exp Dent 6: e138-44.

16. Bagherpour A, Anbiaee N, Partovi P, Golestani S, Afzalinasab S (2012) Dental age assessment of young Iranian adults using third molars: A multivariate regression study. J Forensic Leg Med 19: 407-12.

17. Bhowmik B, Acharya AB, Naikmasur VG (2013) The usefulness of Belgian formulae in third molar-based age assessment of Indians. Forensic Sci Int 226: 300. e1-5.

18. Brough AL, Morgan B, Black S, Adams C, Rutty GN (2014) Postmortem computed tomography age assessment of juvenile dentition: comparison against traditional OPT assessment. Int J Legal Med 128: 653-8.

19. Cameriere R, De Luca S, Alemán I, Ferrante L, Cingolani M (2012) Age estimation by pulp/tooth ratio in lower premolars by orthopantomography. Forensic Sci Int 214: 105-12.

20. Cameriere R, Cunha E, Wasterlain SN, De Luca S, Sassaroli E, et al. (2013) Age estimation by pulp/tooth ratio in lateral and central incisors by peri-apical X-ray. J Forensic Leg Med 20: 530-6.

21. Cantekin K, Yilmaz Y, Demirci T, Celikoglu M (2012) Morphologic analysis of third-molar mineralization for eastern Turkish children and youth. J Forensic Sci 57: 531-4.

22. Cantekin K, Sekerci AE, Buyuk SK (2013) Dental computed tomographic imaging as age estimation: morphological analysis of the third molar of a group of Turkish population. Am J Forensic Med Pathol 34: 357-62.

23. Celik S, Zeren C, Celikel A, Yengil E, Altan A (2014) Applicability of the Demirjian method for dental assessment of southern Turkish children. J Forensic Leg Med 25: 1-5.

24. da Silva RD, da Silva MA, de Oliveira OB, Melo AC, de Oliveira RN (2013) Dental fluorescence: potential forensic use. Forensic Sci Int 231: 167-71.

25. De Luca S, De Giorgio S, Butti AC, Biagi R, Cingolani M, et al. (2012) Age estimation in children by measurement of open apices in tooth roots: Study of a Mexican sample. Forensic Sci Int 221: 155.e1-7.

26. De Luca S, Biagi R, Begnoni G, Farronato G, Cingolani M, et al. (2014) Accuracy of Cameriere's cut-off value for third molar in assessing 18 years of age. Forensic Sci Int 235: 102.e1-6.

27. Djukic K, Zelic K, Milenkovic P, Nedeljkovic N, Djuric M (2013) Dental age assessment validity of radiographic methods on Serbian children population. Forensic Sci Int 231: 398.e1-5.

28. Feijóo G, Barbería E, De Nova J, Prieto JL (2014) Permanent teeth development in a Spanish sample. Application to dental age estimation. Forensic Sci Int 214: 213.e1-6.

29. Feijóo G, Barbería E, De Nova J, Prieto JL (2012) Dental age estimation in Spanish children. Forensic Sci Int 223: $371 . e 1-5$.

30. Flood SJ, Franklin D, Turlach BA, McGeachie J (2013) A comparison of Demirjian's four dental development methods for forensic age estimation in South Australian sub-adults. J Forensic Leg Med 20: 875-83.

31. Galić I, Vodanović M, Janković S, Mihanović F, Nakaš E, et al. (2013) Dental age estimation on Bosnian-Herzegovinian children aged 6-14 years: evaluation of Chaillet's international maturity standards. J Forensic Leg Med 20: 40-5.

32. Gibelli D, De Angelis D, Rossetti F, Cappella A, Frustaci M, et al. (2014) Thermal modifications of root transparency and implications for aging: a pilot study. J Forensic Sci 59: 219-23.

33. Gocha TP, Schutkowski H (2013) Tooth cementum annulation for estimation of age-at-death in thermally altered remains. J Forensic Sci 1: S151-5.

34. Grover S, Marya CM, Avinash J, Pruthi N (2012) Estimation of dental age and its comparison with chronological age: accuracy of two radiographic methods. Med Sci Law 52: 32-5.

35. Ifesanya JU, Adeyemi AT (2012) Accuracy of age estimation using Demirjian method among Nigerian children. Afr J Med Med Sci 41: 297-300.

36. Jatti D, Kantaraj Y, Nagaraju R, Janardhan S, Nataraj S (2013) Age estimation by measuring open apices of lower erupted teeth in 12-16 years olds by radiographic evaluation. J Forensic Leg Med 20: 430-4.

37. Jayaraman J, Roberts GJ, King NM, Wong HM (2012) Dental age assessment of southern Chinese using the United Kingdom Caucasian reference dataset. Forensic Sci Int 216: 68-72.

38. Kanchan-Talreja P, Acharya AB, Naikmasur VG (2012) An assessment of the versatility of Kvaal's method of adult dental age estimation in Indians. Arch Oral Biol 57: 277-84. 
39. Karataş OH, Öztürk F, Dedeoğlu N, Çolak C, Altun O (2013) Radiographic evaluation of third-molar development in relation to the chronological age of Turkish children in the southwest Eastern Anatolia region. Forensic Sci Int 232: 238.e1-5.

40. Karkhanis S, Mack P, Franklin D (2013) Age estimation standards for a Western Australian population using the coronal pulp cavity index. Forensic Sci Int 231: 412.e1-6.

41. Khorate MM, Dinkar AD, Ahmed J (2014) Accuracy of age estimation methods from orthopantomograph in forensic odontology: a comparative study. Forensic Sci Int 234: 184.e1-8.

42. Kırzıoğlu Z, Ceyhan D (2012) Accuracy of different dental age estimation methods on Turkish children. Forensic Sci Int 216: 61-7.

43. Lajolo C, Giuliani M, Cordaro M, Marigo L, Marcelli A, et al. (2013) Two new oro-cervical radiographic indexes for chronological age estimation: a pilot study on an Italian population. J Forensic Leg Med 20: 861-6.

44. Li G, Ren J, Zhao S, Liu Y, Li N, et al. (2012) Dental age estimation from the developmental stage of the third molars in western Chinese population. Forensic Sci Int 219: 158-64.

45. Mohammed RB, Krishnamraju PV, Prasanth PS, Sanghvi P, Lata Reddy MA, et al. (2014) Dental age estimation using Willems method: A digital orthopantomographic study. Contemp Clin Dent 5: 371-6.

46. Mohammed RB, Koganti R, Kalyan SV, Tircouveluri S, Singh JR, et al. (2014) Digital radiographic evaluation of mandibular third molar for age estimation in young adults and adolescents of South Indian population using modified Demirjian's method. J Forensic Dent Sci 6: 191-6.

47. Mohammed RB, Srinivas B, Sanghvi P, Satyanarayana G, Gopalakrishnan M, et al. (2015) Accuracy of Demirjian's 8 teeth method for age prediction in South Indian children: A comparative study. Contemp Clin Dent 6: 5-11.

48. Naik SB, Patil SN, Kamble SD, Mowade T, Motghare P (2014) Reliability of Third Molar Development for Age Estimation by Radiographic Examination (Demirjian's Method). J Clin Diagn Res 8: ZC25-8.

49. Olze A, Hertel J, Schulz R, Wierer T, Schmeling A (2012) Radiographic evaluation of Gustafson's criteria for the purpose of forensic age diagnostics. Int J Legal Med 126: 615-21.

50. Prabhu RV, Satoskar S, Dinkar AD, Prabhu VD (2013) Dental age estimation among female commercial sex workers in Goa. J Forensic Leg Med 20: 788-91.

51. Rai V, Saha S, Yadav G, Tripathi AM, Grover K (2014) Dental and skeletal maturity- a biological indicator of chronologic age. J Clin Diagn Res 8: ZC60-4.

52. Rajkumari S, Nirmal M, Sunil PM, Smith AA (2013) Estimation of age using aspartic acid racemisation in human dentin in Indian population. Forensic Sci Int 228: 38-41.

53. Sakuma A, Saitoh H, Suzuki Y, Makino Y, Inokuchi G, et al. (2013) Age estimation based on pulp cavity to tooth volume ratio using postmortem computed tomography images. J Forensic Sci 58: 1531-5.

54. Sarkar S, Kailasam S, Mahesh Kumar P (2013) Accuracy of estimation of dental age in comparison with chronological age in Indian population--a comparative analysis of two formulas. J Forensic Leg Med 20: 230-3.

55. Shilpa PH, Sunil RS, Sapna K, Kumar NC (2013) Estimation and comparison of dental, skeletal and chronologic age in Bangalore south school going children. J Indian Soc Pedod Prev Dent 31: 63-8.

56. Shrigiriwar M, Jadhav V (2013) Age estimation from physiological changes of teeth by Gustafson's method. Med Sci Law 53: 67-71.

57. Thevissen PW, Kaur J, Willems G (2012) Human age estimation combining third molar and skeletal development. Int J Legal Med 126: 285-92.

58. Thevissen PW, Galiti D, Willems G (2012) Human dental age estimation combining third molar(s) development and tooth morphological age predictors. Int J Legal Med 126: 883-7.

59. Timmins K, Liversidge H, Farella M, Herbison P, Kieser J (2012) The usefulness of dental and cervical maturation stages in New Zealand children for Disaster Victim Identification. Forensic Sci Med Pathol 8: 101-8.

60. Urzel V, Bruzek J (2013) Dental age assessment in children: a comparison of four methods in a recent French population. J Forensic Sci. 58 : 1341-7.

61. Thali MJ, Braun M, Wirth J, Vock P, Dirnhofer R (2003) 3D surface and body documentation in forensic medicine: 3-D/CAD Photogrammetry merged with $3 \mathrm{D}$ radiological scanning. J Forensic Sci 48: 1356-65.

62. Thali MJ, Markwalder T, Jackowski C, Sonnenschein M, Dirnhofer R (2006) Dental CT imaging as a screening tool for dental profiling: advantages and limitations. J Forensic Sci 51: 113-9.

63. Bolliger SA, Thali MJ, Ross S, Buck U, Naether S, et al. (2008) Virtual autopsy using imaging: bridging radiologic and forensic sciences. A review of the Virtopsy and similar projects. Eur Radiol 18: 273-82.

64. Vannier MW, Hildebolt CF, Conover G, Knapp RH, Yokoyama-Crothers N, et al. (1997) Three-dimensional dental imaging by spiral CT. A progress report. Oral Surg Oral Med Oral Pathol Oral Radiol Endod 84: 561-70.

65. Chandler LP, Laskin DM (1988) Accuracy of radiographs in classification of impacted third molar teeth. J Oral Maxillofac Surg 46: 656-60.

66. Yang F, Jacobs R, Willems G (2006) Dental age estimation through volume matching of teeth imaged by cone-beam CT. Forensic Sci Int 1: S78-83.

67. Aboshi H, Takahashi T, Komuro T (2010) Age estimation using microfocus X-ray computed tomography of lower premolars. Forensic Sci Int 200: 35-40.

68. Bassed RB, Briggs C, Drummer OH (2011) Age estimation and the developing third molar tooth: an analysis of an Australian population using computed tomography. J Forensic Sci 56: 1185-91.

69. Demirjian A, Goldstein H, Tanner JM (1973) A new system of dental age assessment. Hum Biol 45: 211-27.

70. Brough AL, Morgan B, Black S, Adams C, Rutty GN (2014) Postmortem computed tomography age assessment of juvenile dentition: comparison against traditional OPT assessment. Int J Legal Med 128: 653-8.

71. AlQahtani SJ, Hector MP, Liversidge HM (2010) Brief communication: atlas of tooth development and eruption. Am J Phys Anthropol 142: 481-90.

72. Demirjian A, Goldstein H (1976) New systems for dental maturity based on seven and four teeth. Ann Hum Biol 3: 411-21.

73. Cantekin K, Sekerci AE, Buyuk SK (2013) Dental computed tomographic imaging as age estimation: morphological analysis of the third molar of a group of Turkish population. Am J Forensic Med Pathol 34: 357-62.

74. Graham JP, O’Donnell CJ, Craig PJ, Walker GL, Hill AJ, et al. (2010) The application of computerized tomography (CT) to the dental ageing of children and adolescents. Forensic Sci Int 195: 58-62. 
75. Moorrees CFA, Fanning EA, Hunt EE (1963) Formation and resorption of three deciduous teeth in children. Am J Phys Anthropol 21 : $205-13$.

76. Moorrees CFA, Fanning EA, Hunt EE (1963) Age variation of formation stages for ten permanent teeth. J Dent Res 42: 1490-502.

77. Lalys L, Ruquet M, Tardivo D, Laibi S, Bartoli C, et al. (2011) Estimation of gestational age from tooth germs: Biometric study of DentaScan images. J Forensic Sci 56: 220-3.

78. Pinchi V, Pradella F, Buti J, Baldinotti C, Focardi M, et al. (2015) A new age estimation procedure based on the 3D CBCT study of the pulp cavity and hard tissues of the teeth for forensic purposes: A pilot study. J Forensic Leg Med 36: 150-7.

79. Sakuma A, Saitoh H, Suzuki Y, Makino Y, Inokuchi G, et al. (2013) Age estimation based on pulp cavity to tooth volume ratio using postmortem computed tomography images. J Forensic Sci 58: 1531-5.

80. Someda H, Saka H, Matsunaga S, Ide Y, Nakahara K, et al. (2009) Age estimation based on three-dimensional measurement of mandibular central incisors in Japanese. Forensic Sci Int 185: 110-4.

81. Star H, Thevissen P, Jacobs R, Fieuws S, Solheim T, et al. (2011) Human dental age estimation by calculation of pulp-tooth volume ratios yielded on clinically acquired cone beam computed tomography images of monoradicular teeth. J Forensic Sci 1: S77-82.

82. Tardivo D, Sastre J, Ruquet M, Thollon L, Adalian P, et al. (2011) Three-dimensional modeling of the various volumes of canines to determine age and sex: a preliminary study. J Forensic Sci 56: 766-70.

83. Vandevoort FM, Bergmans L, Van Cleynenbreugel J, Bielen DJ, Lambrechts P, et al. (2004) Age calculation using X-ray microfocus computed tomographical scanning of teeth: a pilot study. J Forensic Sci 49: 787-90.

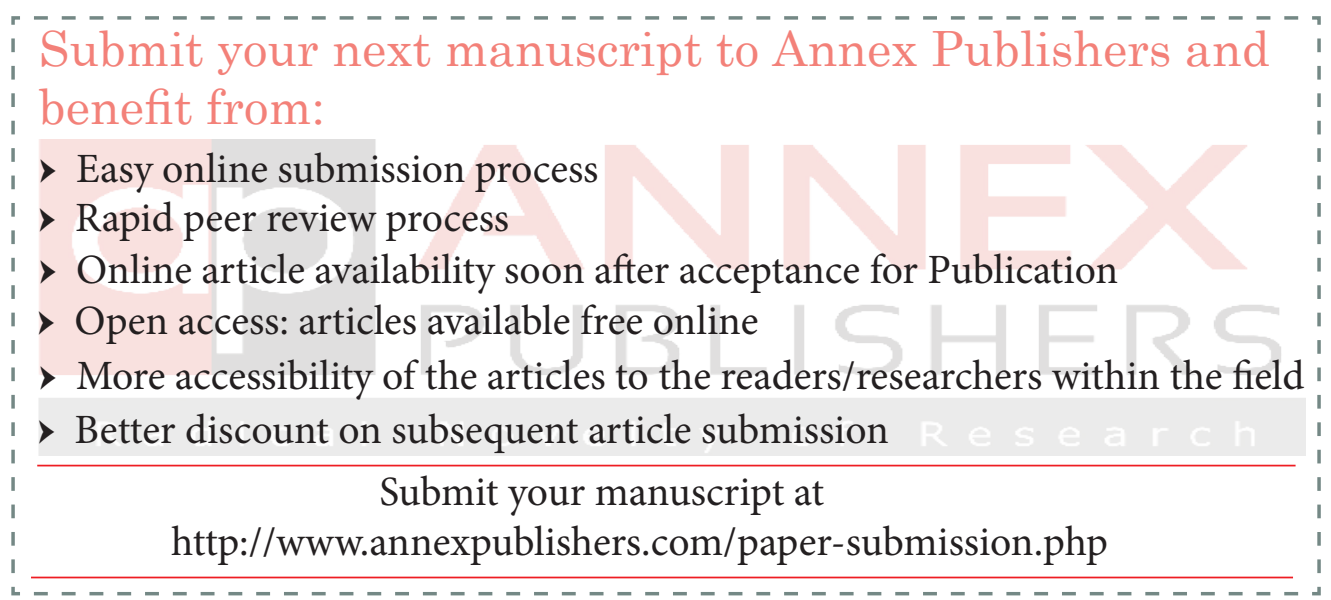

